\title{
Chronic Hepatitis C, Genotyping, Metabolic Status and Body Mass Index in Iranian Population
}

\author{
Shahnaz Sali ${ }^{1 *}$, Seyed Moayed Alavian ${ }^{2}$, Illad Alavi ${ }^{1}$ and Azade Laali ${ }^{1}$ \\ ${ }^{1}$ Infectious Diseases and Tropical Medicine Research Center, Shahid Beheshti University of Medical Sciences, Tehran, Iran \\ ${ }^{2}$ Baqiyatallah Research Center for Gastroenterology and Liver Disease, Tehran, Iran
}

${ }^{*}$ Corresponding author: Shahnaz Sali, Infectious Diseases and Tropical Medicine Research Center, ShahidBeheshti University of Medical Sciences, Tehran, Iran, Tel: +98 212243 9770; E-mail: shakiba416@yahoo.com

Rec date: January 17, 2018; Acc date: January 26, 2018; Pub date: January 30, 2018

Citation: Sali S, Alavian SM, Alavi I, Laali A (2018) Chronic Hepatitis C, Genotyping, Metabolic Status and Body Mass Index in Iranian Population. J Clin Gastroenterol Hepatol Vol.2: No.1:3.

\section{Letter to Editor}

Genotyping, ethnicity, body mass index and the metabolic syndrome are believed to affect progression of hepatitis $C$ virus (HCV) infection [1], but the interaction between these factors is unidentified whereas, it is believed that environmental and host factors mutually impact on HCVrelated liver disease within ethnic groups [2]; we designed this cohort study in order to elucidate the factors responsible for $\mathrm{HCV}$ infection prevalence in Iranian populations.

Well documented environmental elements include alcohol, tobacco, and marijuana which are related to the development of fibrosis [3-5]. While host factors as well as older age and male sex also are correlates with HCV presentation [6]. The relationship between ethnicity, as a host factor, and the progression of HCV has not still been explained [7], while large cohort data are scarce too. For example, the metabolic syndrome prevalence was more frequent in Hispanics [8] and steatohepatitis and fibrosis were seen in non-Hispanic white and Hispanic obesity surgery patients compared with African Americans [9]. In addition, tobacco and opium dependency also may differ by ethnicity. Opium addiction in Iran is a serious national problem [10]. On the other hand, because Iran is of a passage of drug and opiate trafficking from east Asia to Europe [11], it may affect Iranian's opiate dependency and virologic features in return.

The current study represents a cross sectional analysis of a large HCV screening project at a referral clinic in Tehran since 2006 to 2013 with an aim to assess demographic, epidemiologic, body mass index (BMI) and virologic features as well as triglyceride, cholesterol and liver biochemistry. After approval by our institutional ethics committee and obtaining informed consent, 83 consecutive patients, confirmed by HCVRNA test, were included in the study and mentioned data was gathered. The median age was $46.5 \pm 12.8,61$ patients were male and 22 female. HCV genotype 1 was predominantly seen (64\%); the most frequent subtype was $1 \mathrm{a}$ followed by $1 \mathrm{~b}$ and $29.3 \%$ were genotype 3 . Moreover, genotypes did not vary among other demographic and metabolic factors in this study. The mean of patients' BMI was $24.98 \pm 3.9 \mathrm{~kg} / \mathrm{m}^{2}$. Hypertriglyceridemia (serum triglyceride $>150 \mathrm{mg} / \mathrm{dl}$ ) and hypercholesterolemia (total cholesterol $\geq 240 \mathrm{mg} / \mathrm{dl}$ ) was seen in $24.4 \%$ and $7.3 \%$ of patients, respectively. Finaly, there was no correlation between aminotransferases, albumin, age and $\mathrm{BMI}$ of patients withserum triglyceride andcholesterol $(p>0.05)$.

In general, Iranian genotyping was very similar to epidemiologic data of European countries despite position of our country in the Middle East, which indicate that the pattern of genotypes is somehow unusual. Our results validate previous studies evidence [12], that may also explicate our local antiviral regimen need. In addition, the frequency of hypertriglyceridemia and hypercholesterolemia were not higher than Iranian normal population according to retrieved data from previous country-wide studies $[13,14]$.

In summary, based on these reports, all our patients can undergo a specific therapeutic protocol according to the underling genotyping status. Furthermore there were no differences between lipid profile and other possible factors evaluated in this study.

\section{References}

1. Younossi ZM, McCullough AJ (2009) Metabolic syndrome, nonalcoholic fatty liver disease and hepatitis $C$ virus: Impact on disease progression and treatment response. Liver Int 29: 3-12.

2. Shalmani HM, Ranjbar M, Alizadeh AH (2013) Recommendations for prevention and control of hepatitis $C$ virus (HCV) infection and HCV-related chronic disease. J Liver 3: 2167-0889.

3. Wiley TE, McCarthy M, Breidi L, McCarthy M, Layden TJ (1998) Impact of alcohol on the histological and clinical progression of hepatitis C infection. Hepatol 28: 805-809.

4. Ishida JH, Peters MG, Jin C, Louie K, Tan V, et al. (2008) Influence of cannabis use on severity of hepatitis $C$ disease. Clin Gastroenterol Hepatol 6: 69-75.

5. Dev A, Patel K, Conrad A, Blatt LM, McHutchison JG (2006) Relationship of smoking and fibrosis in patients with chronic hepatitis C. Clin Gastroenterol Hepatol 4: 797-801.

6. Poynard T, Bedossa P, Opolon P (1997) Natural history of liver fibrosis progression in patients with chronic hepatitis $C$. The Lancet 349: 825-832. 
7. Petta S, Cammà C, Di Marco V, Alessi N, Cabibi D, et al. (2008) Insulin resistance and diabetes increase fibrosis in the liver of patients with genotype $1 \mathrm{HCV}$ infection. Am J Gastroenterol 103: 1136-1144.

8. Ford ES, Giles WH, Dietz WH (2002) Prevalence of the metabolic syndrome among US adults: findings from the third National Health and Nutrition Examination Survey. JAMA 287: 356-359.

9. Kallwitz ER, Guzman G, TenCate V, Vitello J, Layden-Almer J, et al. (2009) The histologic spectrum of liver disease in AfricanAmerican, non-Hispanic white, and Hispanic obesity surgery patients. Am J Gastroenterol 104:64-69.

10. Maisto SA, Galizio M, Connors GJ (2014) Drug use and abuse. Cengage Learning.
11. Agahi C, Spencer CP (1981) Drug abuse in pre-and postrevolutionary Iran. J Psychoactive Drugs 13: 39-46.

12. Miyanari Y, Atsuzawa K, Usuda N, Watashi K, Hishiki T, et al. (2007) The lipid droplet is an important organelle for hepatitis $C$ virus production. Nat Cell Biol 9: 1089-1097.

13. Hosseini-Esfahani F, Khameneh AM, Mirmiran P, Ghanbarian A, Azizi $F$ (2011) Trends in risk factors for cardiovascular disease among Iranian adolescents: The Tehran lipid and glucose study, 1999-2008. J Epidemiol 21: 319-328.

14. Chehrei A, Sadrnia S, Keshteli AH, Daneshmand MA, Rezaei J (2007) Correlation of dyslipidemia with waist to height ratio, waist circumference, and body mass index in Iranian adults. Asia Pac J Clin Nutr 16: 248-253. 